DOI: https://doi.org/10.32839/2304-5809/2021-5-93-13

УДК 378.14(430)

Кравченко О.Л.

Донецький національний університет економіки і торгівлі імені Михайла Туган-Барановського

\title{
СТРУКТУРА ПРОФЕСІЙНОЇ ДІЯЛЬНОСТІ ФАХІВЦІВ З ХАРЧОВИХ ТЕХНОЛОГІЙ ЗА ДУАЛЬНОЮ ФОРМОЮ ЗДОБУТТЯ ОСВІТИ
}

Анотація. У статті проаналізовано структуру професійної діяльності фахівців з харчових технологій, виділено різноманітні підходи до вивчення її компонентів. Відзначено, що проблема вдосконалення професійної підготовки спеціалістів для різних галузей народного господарства з кожнним роком набуває все більшої актуальності. Об'рунтовано теоретичні аспекти професійної підготовки фрахівців з харчових технологій за умови реалізації дуальної фрорми здобуття освіти. До особливостей такої підготовки віднесено: системність та послідовність, тісний зв'язок теоретичної та професійно-практичної складової навчання, відтворення виробничих процесів, соціального змісту профресії, адаптація випускників закладів освіти до першого робочого місця, оптимальне співвідношення навчальних методів, прийомів, технологій для вирішення навчальних та виробничих завдань. Визначено, що профресійна діяльність фрахівців з харчових технологій вимагає наявності спеціальних знань, вмінь, навичок, ціннісних орієнтащій, мотивацій, психологічної готовності до виконання виробничих дій. Серед структурних компонентів такої діяльності виокремлено стратегічні цілі, фрункції та завдання, для реалізації яких випускникові необхідно мати сформовані на належному рівні професійні компетенції. Вони відображають зміст і характер діяльності та слугують орієнтиром для реалізації дуального освітнього процесу. Зміст типових завдань професійної діяльності та їі фрункції обумовлені особливостями виробничої галузі (підгалузі), характером економічної діяльності суб’єкта господарювання. У структурі професійної діяльності також визначено різноманітні соціальні, психологічні та професійні аспекти.

Ключові слова: вища освіта, якість освіти, дуальна освіта, освітній процес, учасники дуальної освіти, держава, підприємство, роботодавець, майбутній фахівець.

Kravchenko Olga

Mykhailo Tuhan-Baranovskyi Donetsk National University of Economics and Trade

\section{THE STRUCTURE OF PROFESSIONAL COMPETENCE OF FOOD TECHNOLOGY SPECIALISTS IN THE DUAL FORM OF EDUCATION}

Summary. The article analyzes the structure of professional activity of food technology specialists and it highlights various approaches to the study of its components. It is noted that the problem of improving the training of specialists for various sectors of the economy is becoming more relevant every year. Among the ways which improve the quality of the educational process is the introduction of a dual form of education. Theoretical aspects of professional training of food technology specialists under the condition of realization of the dual form of education are substantiated. Among the features of such training, we can name systematic nature and consistency, the close connection of theoretical, professional, and practical components of training, reproduction of manufacturing processes, social content of the profession, adaptation of graduates to the entry-level position, the optimal ratio of teaching methods, techniques, technologies in order to solve educational and production tasks. It is determined that the professional activity of a food technology specialist requires special knowledge, skills, abilities, system of values, motivation, psychological readiness to perform production functions. It is important to create the personal and professional qualities of food technology professionals, their professional culture. The model of professional activity of a specialist is considered as an integrative concept that includes such structural elements as "activity» and "occupational activityn. Among the structural components of the professional activity of the specialist, we identify strategic goals, functions, and objectives, for the implementation of which the graduate must have the appropriate level of professional competencies. They reflect the content and kind of activities and serve as a guide for the implementation of the dual educational process. The content of typical tasks of professional activity and its functions is determined by the special aspects of the production industry (subsector), the nature of the economic activity of the business entity. Various social, psychological, and professional aspects are also noted in the structure of professional activity.

Keywords: higher education, quality of education, educational process, dual education participants, state, enterprise, employer, future specialist.

Постановка проблеми. В умовах модер1 нізації вітчизняної системи освіти, ії інтеграції у світовий освітній простір змінюються завдання та структура професійної підготовки фахівців [3, с. 131-132]. Особливої актуальності набувають питання підготовки висококваліфікованих, конкурентоспроможних виробничих кадрів, посилення практичної спрямованості навчального процесу. Реалізація означених завдання пов'язана 3 впровадженням дуальної форми здобуття освіти, що забезпечуе інтеграцію освіти, виробництва, ринку праці, виступае механізмом підвищення якості надання освітніх послуг, забезпечуе опанування студентами професійно важливих вмінь та навичок, забезпечуе адаптацію випускників навчальних закладів до реалій виробничого середовища $[17$, с. $62-64]$.

Варто погодитись 3 думкою науковців С. Артюха та А. Ашерова, які вважають, що студенти повинні одержати під час навчання не тільки необхідні вміння чи навички, але й навчитись використовувати їх при виконанні виробничих дій [2, с. 35-39].

Аналіз останніх досліджень і публікацій. У контексті даної статті інтерес представляють 
роботи В. Зінченко [9], О. Файер [20], І. Сабатовської та Л. Кайдалової [16], в яких розглядаються ознаки та особливості профресійної діяльності фрахівців різних профрілів. Характеристика структура професійної діяльності фрахівців та їі складових досліджена В. Ковальчук [11], Г. Гайдук [6], О. Столяренко [19] та ін.

Проблема визначення вимог до структури професійної діяльності фрахівців та її складових знайшла відображення у наукових працях О. Грохольської та Н. Никандрова [8], Г. Слозанської [18], ін.

Доцільність впровадження та реалізації дуальної форми здобуття освіти та їі відображення у структурі профресійної діяльності фрахівців обгрунтовано I. Андрейцевим [1], В. Вем'яном [5], В. Тер-Ованес'яном [5], О. Кравченко, Р. Никифоровим та Т. Старовою [22], ін.

Питання інтегращії освіти, науки, бізнесу розглядаються у дослідженнях вчених Л. Овсиенко, И. Зиминой, Е. Есениной [13] та ін.

Виділення не вирішених раніше частин загальної проблеми. Аналіз публікацій вітчизняних й зарубіжних науковців й дослідників свідчить про те, що структура профресійної діяльності фрахівців з харчових технологій за дуальної форми здобуття освіти досліджена недостатньо в теоретичному та практичному аспектах.

Мета статті полягае у проведенні аналізу структури та особливостей професійної діяльності фахівців з харчових технологій за дуальною формою здобуття освіти.

Виклад основного матеріалу. Проблема профресійного становлення молодих фрахівців, ï готовності до виконання виробничих дій посідає важливе місце у сучасній науковій думці. Дослідник В. Биков відзначає, що підготовка сучасного фрахівця має задовольняти потребам держави та ринку праці у розвитку робочої сили [4, с. 59-80]. Суголосною цьому є думка вчених С. Немченка, О. Голіка та О. Лебідь, які вважають, що реалізація основних освітніх завдань відповідає процесам розвитку та модернізації суспільства [12, с. 34]. Це стосуеться й вимог до якості підготовки фрахівців.

Харчова промисловість належить до системоутворюючих й стратегічно важливих галузей вітчизняної промисловості, провідних елементів економіки. Ïї розвиток залежить не лише від розробки, впровадження, сертифікащії сучасних виробничих технологій, але й від якості праці й конкурентоспроможності фрахівців підприемств харчової галузі, підготовка яких здійснюеться закладами вищої освіти України, їх затребуваності на ринку праці [21, с. 13-14]. Серед основних завдань підготовки майбутніх фpaхівців харчової промисловості варто відзначити формування високого рівня їх профресійної компетентності, адаптацію до умов й реалій виробничого середовища, розвиток профресійно значущих якостей особистості [14, с. 103-104]. Одним з напрямів поліпшення профресійної підготовки майбутніх фpaхівців 3 харчових технологій вважаємо впровадження дуальної форми здобуття освіти. Ї̈̈ реалізація передбачає інтеграцію теоретичної та практичної складової освітнього процесу, максимальне наближення навчання до виробничих реалій, ознайомлення студентів з сучасними технологіями [7]. За таких умов особливого значення та якісного переосмислення потребують змісту підготовки майбутніх фахівців з харчових технологій, оновлення моделей та структури їх профресійної діяльності.

У рекомендаціях міжнародного семінару «A Framework for Qualifications of the EHEA» наголошується, що зміст підготовки здобувачів освіти повинен відображати специфріку їх майбутньої професійної діяльності [22, с. 88-89]. Вважаємо, що саме намагання наукового співтовариства Європи сорормулювати уніфіковані вимоги до змісту професійної підготовки та ощінювання професійної компетентності майбутніх фрахівців актуалізували інтеграційні процеси освітнього та виробничого середовища, розвиток дуальної форми здобуття освіти. Актуальності та важливості набувають питання підготовки фахівців 3 харчових технологій, адаптованих до виконання виробничих дій та завдань, змісту їх фрункціональних обов'язків [1].

Проаналізуемо структуру та особливостей профресійної діяльності фрахівців з харчових технологій за дуальною формою здобуття освіти. У сучасній науковій літературі «професійна діяльності фрахівця» визначаеться як комплексне поняття, що інтегрує такі складові як «діяльність» та «професійна діяльність», надає можливість уточнити ї сутнісні характеристики. Дефініція «діяльність» визначається як взаємодія людини 3 навколишнім світом, що забезпечує перетворенню дійсності та задоволення потреб особистості [16, с. 15]; специфічний спосіб перетворення людиною природи, самого себе [20, с. 126-127]. Поняття «діяльність» також розглядаеться науковцями у психологічному, соціологічному та філософському аспектах.

Серед різних видів діяльності особливе місце займає "професійна», адже саме вона є складовою кожного виду діяльності. «Професійна діяльність» забезпечуе активність та соціалізацію суб'єкта, розвиток його особистості, надає можливість задовольнити індивідуальні потреби, розкриває мотиви, стимули [18, с. 241]. Цей вид діяльності також вирізняеться від інших рядом особливостей, серед яких варто відзначити:

- чітке розуміння мети, основних завдань та очікуваних результатів профресійної діяльності;

- форомування системи профресійних компетенцій фрахівців;

- свідомий вибір шляхів виконання виробничих завдань, досягнення результатів;

- регламентований та визначальних характер взаємовідносин та моделей поведінки у колективі;

- готовність індивіда до виконання профресійних фрункцій [18, с. 241-243].

Зміст професійної діяльності визначають сукупність виробничий дій та операцій, що виконують працівники, спілкування та комунікації, особистісний розвиток, загальні результати праці.

Структура професійної діяльності фрахівця 3 харчових технологій є складною, багатокомпонентною системою, що складається із сукупності взаємопов'язаних між собою елементів. Саме вони конкретизують цілі, завдання, потреби діяльності та забезпечують досягнення високих результатів праці, успішне виконання виробничих фрункцій [20, с. 126-127].

Аналіз наукових підходів до розуміння структури профресійної діяльності фрахівця та змісту цієї діяльності дозволяють виокремити різні 
точки зору сучасних науковців. Зокрема, увага акцентуеться на особливостях профресійної діяльності фрахівців певної галузі чи профрілю, моделюванні дидактичних складових їх профресійної підготовки, визначенні характеристик та особливостей цієї діяльності, дієвих чинників фрормування профресійної компетентності [9, с. 72; 16, с. 80-87]. Так, структура профресійної діяльності фрахівця за О. Пономарьовим передбачає виокремлення виробничої та соціальної складових. Виробничу науковець поєднує з виконанням великої кількості посадових обов'язків, вирішенням виробничих завдань. Соціальну пов'язує з вирішенням конфрліктних ситуащій та проблем, комунікацією, виконанням складних виробничих завдань. Кожна з визначених складових від- повідає класам типовим завданням діяльності: діагностичним (характеризують фрактичний стан виробничого процесу чи об'єкту); стереотипним (виконуються відповідно до заданого алгоритму); евристичним (передбачають складні алгоритми дії та самостійне конструювання фрахівцем виробничих завдань 3 подальшим їх розв'язанням) [15, с. 9-10]. Для реалізації кожного з означених завдань фрахівцеві необхідні сорормовані вміння, навички та здатності, що відповідають специфіці профресійної діяльності фрахівця та характеризуються певним рівнем сорормованості компетентностей [15, с. 12-15]. До основних видів умінь О. Пономарьов відносить:

- предметно-практичні (застосовуються для зміни форми чи стану об’єктів);

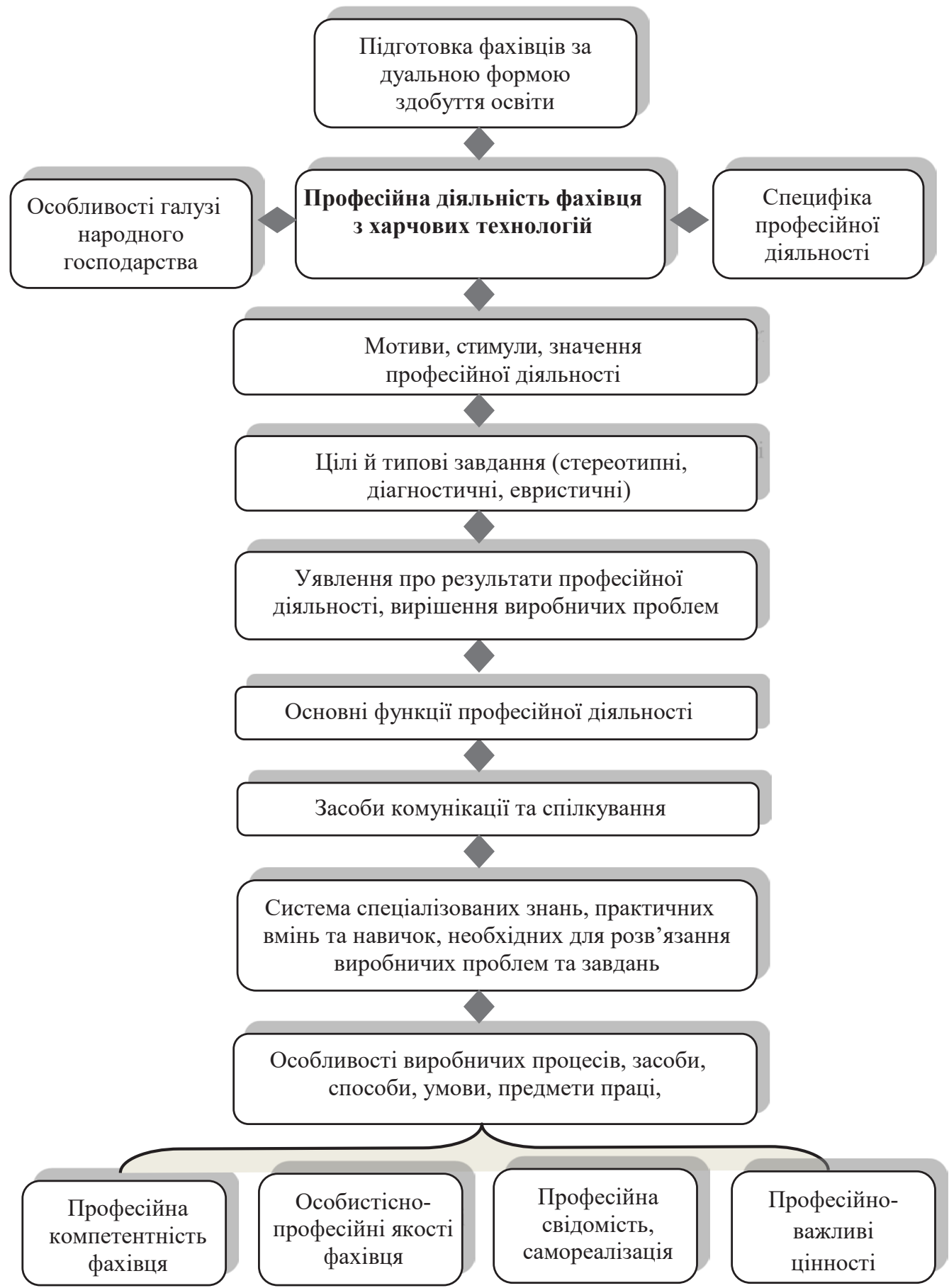

Рис. 1. Структура професійної діяльності фахівця з харчових технологій 
- предметно-розумові (спрямовані на аналіз, порівняння, дифреренціацію, узагальнення умовних чи розумових образів);

- знаково-розумові (застосування знакових систем, розумові операції із символами, знаками);

- знаково-практичні (дії із знаками чи символами як моделями певних явищ; складання креслень, ескізів, отримання та обробка інфрормації з певних пристроїв) [15, с. 12-13] .

Погоджуючись 3 думкою О. Пономарьова, вважаємо типові завдання, виробничі фрункції, вміння, навички важливими складовими структури профресійної діяльності фрахівців 3 харчових технологій.

У структурі профресійної діяльності фрахівця науковці О. Грохольська та Н. Никандров визначають: мету, завдання, мотиви, індрормацію та іï відповідність знанням фрахівців й реаліям виробництва, засоби комунікації, рівень підготовки колективу та окремих фрахівців до виконання виробничих дій, організаційну складову, фрункції працівників та умови для їх реалізащії, функціональні елементи [8, с. 19]. Останні класифрікуються на гностичні (оволодіння сучасними харчовими технологіями, оцінка трудових відносин, розподіл та виконання виробничих завдань, вирішення проблем й технологічних завдань приготування страв), прогностичні (планування діяльності, передбачення ії результатів), конструктивні (досягнення профресійних цілей, системність у виконанні виробничих завдань, злагоджена взаємодія всіх учасників виробничого процесу), проектувальні (розуміння фрахівцями цілісності технологічного процесу, кінцевої мети та результатів власної діяльності, узгодженість та поетапність виконання виробничих дій, процесів) організаторські (налагодження взаємодії та корегування діяльності всіх пращівників різних ланок), діагностичні (забезпечення постійного оновлення асортименту продукції, обладнання налагодження й регулювання нових технологій виробництва), інфрормащійноаналітичні (пошук нової інфрормації), контролюючі (саморозвиток, самовдосконалення, підвищення квалірікащії працівників, використання творчого підходу, креативність). Профресійна діяльність фрахівця 3 харчових технологій також характеризується сукупністю когнітивних, мотиваційних, операторних компонентів, усвідомленням соціальної значущості та необхідності результатів ціеї діяльності [15, с. 11-13].

Вважаємо, що результативність профресійної діяльності фрахівців з харчових технологій залежить від сорормованості програмних компетенщій, професійно-важливих цінностей й особистіснопрофресійних якостей працівника спеціальної підготовки до виконання певних трудових операцій, дій, використання знарядь й предметів праці.

Висновки та пропозиції. Результати здійсненого аналізу дають підстави стверджувати, що структура професійної діяльності фрахівця 3 харчових технологій $є$ важливою складовою побудови моделі його профресійної діяльності. Всі змістовні елементи у структурі профресійної діяльності фрахівця 3 харчових технологій взаємопов'язані між собою. У своїй цілісності та єдності вони забезпечують виконання фрахівцем важливих фрункцій трудової діяльності, спрямовані на реалізацію профресійного, особистісного й творчого потенціалу робітника, його відповідність умовам ринку пращі. Модернізація та оновлення вимог до особистісних та професійних характеристик фрахівця з харчових технологій, рівня оволодіння ним комплексом спеціалізованих знань, вмінь навичок призводять до змін у змісті вищої освіти. Зокрема, одним з пріоритетних напрямів розвитку освітнього середовища стає дуальна форма здобуття освіти [6, с. 73-74].

\section{Список літератури:}

1. Андрейців I. Що таке дуальна освіта i навіщо вона українцям. Українська правда. Київ, 2017. URL: https://life.pravda.com.ua/society/2017/02/16/222630/ (дата звернення: 21.03.2021).

2. Артюх C., Ашеров А. Инженерно-педагогическое образование в Украине: состояние и перспективы. Новий колегіум. 2000. № 1. С. 35-39.

3. Батечко Н.Г. Підготовка викладачів вищої школи в умовах магістратури: теоретико-методологічні засади. Київ : Едельвейс, 2014. 708 с.

4. Биков В.Ю. Навчальне середовище сучасних педагогічних систем. Профбесійна освіта: педагогіка $i$ психологія. Украӥно-польський журнал. Вид. IV. Ченстохова : Видавництво Вищої педагогічної школи у Ченстохові, 2004. C. $59-80$.

5. Вем'ян В.Г., Тер-Ованес'ян В.Г. Дуальна форма професійної освіти як умова ефрективного рішення завдань модернізації освіти. Психологія : реальність і перспективи : збірник наукових праць. Рівне, 2015. Вип. 5. С. $29-34$.

6. Гайдук Г. Модель структурної організації професійної толерантності педагога. Психологічні перспективи. 2018. № 32. С. 73-85.

7. Григорьева Н.В., Швец Н.А. Модель подготовки специалистов в условиях дуального обучения. Совреленные проблель науки и образования. URL: https://science-education.ru/ru/article/view?id=25763 (дата звернення 17.03.2021).

8. Никандров Н., Грохольская О. Профессиональная деятельность, её сущность, структура и содержание. Научные исследования в образовании. 2012. № 11. С. 19.

9. Зінченко В.О. Теоретичні основи побудови моделі сучасного фрахівця. Науковий вісник ЛНУ. 2009. 74 с.

10. Методичні вказівки щодо семінарських занять та самостійної роботи з навчальної дисципліни «Моделювання діяльності сучасного викладача» для аспірантів денної форми навчання за напрямом 015 - «Професійна освіта» / укладач канд. пед. наук, доц. С.М. Сошенко та ін. Кременчуг, 2018. С. 13-15.

11. Моделювання діяльності фрахівця: методичні рекомендації для самостійної роботи студентів / В.М. Ковальчук та ін. Івано-Франківськ : Видання Прикарпат. нац. ун-ту. ім. В. Стефраника, 2016. 50 с.

12. Немченко С.Г. Педагогіка вищої школи : підручник для студ. ВНЗ / С.Г. Немченко, О.Б. Голік, О.В. Лебідь. Донецьк : ЛАНДОН-ХХІ, 2014. 534 с.

13. Овсиенко Л.В., Зимина И.В., Есенина Е.Ю. Дуальное обучение как важный фрактор повышения инвестиционной привлекательности региона. Вестник Казанского технологического университета. 2014. Т. 17 . № 5. C. 339-344.

14. Олексін Ю.П., Якубовська С.С. Педагогічна супервізія як елемент індивідуалізації дуального навчання. Молодь і ринок. 2019. № 4.1 (56.1). С. 102-105.

15. Пономарьов О.С., Середа Н.В., Чеботарьов М.К. Моделювання діяльності фрахівця. Харків : НТУ «ХПІ», 2015.58 с.

16. Сабатовська I.С., Кайдалова Л.Г. Моделювання діяльності фрахівця : навчальний посібник. Харків, 2014.180 с. 
17. Сидакова Л.В. Сущность и основные признаки дуальной модели обучения. Образование и воспитание. 2016. № 2. C. 62-64.

18. Слозанська Г.І. Доцільність застосування моделювання професійної діяльності у підготовці майбутніх фрахівців ВНЗ. Актуальні проблели гуланітарних наук у дослідженні молодих вчених : матеріали V Міжнародної наук.- практ. конференції, м. Київ, 1 жовтня 2016 р. Київ, 2016. С. 241-243.

19. Столяренко О.В. Моделювання педагогічної діяльності у підготовці фахівця : навч.-метод. посібник. Вінниця : Нілан-ЛТД, 2015. 196 с.

20. Файер О.А. Поняття професійної діяльності та їі структурні елементи. Університетські наукові записки. 2009. № 3. C. 126-131.

21. Шерман Є.M. Організаційно-економічний механізм розвитку підприемств харчової промисловості : дис. канд. ек. наук. М-во освіти і науки України. Херсонський національний технічний Університет. Херсон, 2015.247 с.

22. Kravchenko O., Starova T., Nykyforov R. World models of dual education and features or their functioning. AD ALTA: journal of interdisciplinary research. 2021. Vol. 11/01 (XV). P. 87-91.

\section{References:}

1. Andrejciv I. (2017) Shho take dualna osvita i navishho vona ukrayincyam [What is dual education and why it is for Ukrainians]. Ukrayinska pravda. Kyiv. Available at: https://ife.pravda.com.ua/society/2017/02/16/222630/ (accessed 21 March 2021).

2. Artiukh S., Asherov A. (2000) Ynzhenerno-pedahohycheskoe obrazovanye v Ukrayne: sostoianye y perspektyvi. [Engineering and pedagogical education in Ukraine: state and prospects]. Novyi kolehium, no. 1, pp. 35-39.

3. Batechko N. H. (2014) Pidhotovka vykladachiv vyshchoi shkoly v umovakh mahistratury: teoretyko-metodolohichni zasady [Training of higher school teachers in the conditions of master's degree: theoretical and methodological principles]. Kyiv: Edelveis, 708 p. (in Ukrainian)

4. Bykov V. Yu. (2004) Navchalne seredovyshche suchasnykh pedahohichnykh system [Learning environment of modern pedagogical systems]. Profesiina osvita: pedahohika i psykholohiia. Ukraino-polskyi zhurnal, vol. IV. Chenstokhova: Vyd-vo Vyshchoi pedahohichnoi shkoly u Chenstokhovi, pp. 59-80.

5. Vemyan V. G., Ter-Ovanesyan V. G. (2015) Dualna forma profesijnoyi osvity yak umova efektyvnogo rishennya zavdan modernizaciyi osvity [Dual form of vocational education as a condition for effective solution of problems of modernization of education]. Psyxologiya: realnist i perspektyvy: zb. nauk. pr. Rivne, no. 5, pp. 29-34.

6. Haiduk H. (2018) Model strukturnoi orhanizatsii profesiinoi tolerantnosti pedahoha [Model of structural organization of professional tolerance of a teacher]. Psykholohichni perspektyvy, no. 32, pp. 73-85.

7. Grigoreva N. V., Shvets N. A. Model podgotovki spetsialistov v usloviyah dualnogo obucheniya [Model of training of specialists in conditions of dual education]. Sovremennyie problemyi nauki i obrazovaniya. Available at: https://science-education.ru/ru/article/view?id=25763 (accessed 17 March 2021). (in Russian)

8. Nykandrov N., Hrokholskaia O. (2012). Professyonalnaia deiatelnost, sushchnost, struktura y soderzhanye [Professional activity, its essence, structure and content]. Nauchnie ysledovanyia v obrazovanyy, no. 11, 19 p.

9. Zinchenko V. O. (2009) Teoretychni osnovy pobudovy modeli suchasnoho fakhivtsia [Theoretical bases of construction of model of the modern expert]. Naukovyi visnyk LNU, $74 \mathrm{p}$.

10. Metodychni vkazivky shchodo seminarskykh zaniat ta samostiinoi roboty z navchalnoi dystsypliny Modeliuvannia diialnosti suchasnoho vykladacha dlia aspirantiv dennoi formy navchannia za napriamom 015 - Profesiina osvita (2018) [Methodical instructions on seminars and independent work on the subject Modeling the activities of a modern teacher] / Ukladach kand. ped. nauk S. M. Soshenko. Kremenchuh, 62 p.

11. Modeliuvannia dialnosti fakhivtsia: metodychni rekomendatsii dlia samostiinoi roboty studentiv (2016) [Modeling of the specialists activity: Methodical recommendations for independent work of students] / avt.-uporiad. V. M. Kovalchuk. Ivano-Frankivsk: Vyd. Prykarpat. nats. un-tu. im. V. Stefanyka, 50 p. (in Ukrainian)

12. Nemchenko S. H. (2014). Pedahohika vyshchoi shkoly: pidruchnyk dlia stud [Pedagogy of a school of food]. VNZ / S. H. Nemchenko, O. B. Holik, O. V. Lebid. Donetsk, 534 p. (in Ukrainian)

13. Ovsienko L. V., Zimina I. V., Esenina E. Y. (2014) Dualnoe obuchenie kak vazhnyj faktor povysheniya investicionnoj privlekatelnosti regiona [Dual education as an important factor in increasing the investment attractiveness of the region]. Vestnik Kazanskogo tekhnologicheskogo universiteta, no. 17/5, pp. 339-344. (in Russian)

14. Oleksin Yu.P., Yakubovska S.S. (2019) Pedahohichna superviziia yak element indyvidualizatsii dualnoho navchannia [Pedagogical supervision as an element of individualization of dual learning]. Molod $i$ rynok, no. 4.1 (56.1), pp. 102-105.

15. Ponomarov O. S., Sereda N. V., Chebotarov M. K. (2015) Modeliuvannia diialnosti fakhivtsia [Modeling the activities of a specialist]. Kharkov: NTU, 58 p. (in Ukrainian)

16. Sabatovska I.S., Kaidalova L.H. (2014) Modeliuvannia diialnosti fakhivtsia [Modeling the activities of a specialist]: navch. posibnik. Kharkiv, 180 p. (in Ukrainian)

17. Sidakova L. V. (2016) Sushchnost y osnovnie pryznaky dualnoi modely obuchenyia [The essence and main features of the dual learning model]. Obrazovanie $i$ vospitanie, no. 2, pp. 62-64. (in Russian)

18. Slozanska G. I. (2016) Docilnist zastosuvannya modelyuvannya profesijnoyi diyalnosti u pidgotovci majbutnix faxivciv VNZ [Expediency of application of modeling of professional activity in preparation of future experts]. Aktualni problemy gumanitarnyx nauk u doslidzhenni molod x vchenyx: materialy V Mizhnar. nauk.-prakt. int.konf., Kiev, pp. 241-243.

19. Stoliarenko O. V. (2015) Modelyuvannya pedahohichna diyalnosti u pidhotovtsi fakhivtsia [Modeling of pedagogical activity in specialist training]: navch.-method. posibnik, Vinnytsia, 196 p. (in Ukrainian)

20. Faier O. A. (2009) Poniattia profesiinoi diialnosti ta yii strukturni elementy [Modeling of pedagogical activity in specialist training]. Universytetski naukovi zapysky, no. 3, pp. 126-131.

21. Sherman Ye. M. (2015) Orhanizatsiino-ekonomichnyi mekhanizm rozvytku pidpryiemstv kharchovoi promyslovosti: dys. kand. ek. nauk. M-vo osvity i nauky Ukrainy [Organizational and economic mechanism of development of enterprises of food industry: dis. Cand. ek. Science]. Khersonskyi natsionalnyi tekhnichnyi Universytet. Kherson, 247 p. (in Ukrainian)

22. Kravchenko O., Starova T., Nykyforov R. (2021) World models of dual education and features or their functioning. AD ALTA: journal of interdisciplinary research, vol. 11/01 (XV), pp. 87-91. 